\title{
THE MONARCH AND INNER-OUTER COURT DUALISM IN LATE IMPERIAL CHINA
}

\author{
Sabine Dabringhaus
}

For more than two millennia, the emperor was the most important symbol of China's unity. In traditional Chinese thought, he mediated as the "son of heaven" (tianzi) between "all under heaven" (tianxia) and the cosmic world. From the first dynasty, founded by Qin Shihuangdi in $221 \mathrm{BCE}$, emperors represented the head of the government, but real power often rested in the hands of prime ministers. Only under the Ming dynasty was this influential position finally abolished and the emperor able to assume personal control of the government. Historians in China and abroad have often characterized Ming rule, as well as its successor, the Qing political system, as the height of autocracy—or even despotism. This image requires reconsideration.

The founding of the Ming dynasty in 1368 marked the beginning of the late imperial era in Chinese history. After a century of Mongol rule under the Yuan dynasty (1271-1368), Chinese government was restored by a native monarchy. Outwardly, the Ming dynasty (13681644) appeared as a period of powerful autocratic rule. The founder Taizu (r. 1368-1398) created a strong, assertive and highly centralized government. The emperor's purview was comprehensive: he was the final author of the state's political decisions, its supreme legislator, the commander of its military forces, the highest patron of religious institutions and the foremost sponsor of arts and letters.

The rulers of the Qing dynasty (1644-1911), originating from the northern frontier, successfully amalgamated the image of late imperial emperorship with the tradition of Inner Asian khanship. As far as ruling over China proper was concerned, they largely perpetuated the institutions of the Ming state. The pre-conquest Qing adoption of Chinese techniques of governance helps to explain the dynasty's effectiveness and staying power. ${ }^{1}$ In fact, the Manchu emperors created a bifurcated system of governance, separating the bureaucratic model

${ }^{1}$ H. Lyman Miller, 'The Late Imperial State', in: The Modern Chinese State, David Shambaugh, ed. (Cambridge 2000) pp. 15-41, here p. 16. 
of the Ming dynasty, applied to the administration of China proper, from the banner system used for controlling the north-eastern Manchu homeland and the Inner Asian frontier. The "national" Ming state evolved into a multiethnic empire that prefigured the framework of the modern Chinese nation-state of the twentieth century. Important sources of this enormous political success were new methods in court politics introduced by the Qing monarchs.

As in Europe, the monarchical court represented the centre of the dynastic state. From the Han dynasty (206 BCE to $220 \mathrm{CE}$ ), Chinese court society was divided into an inner and an outer part, separating the personal household of the emperor from the central bureaucratic administration of the state. Thus, China had overcome feudal structures much earlier than Europe. From the late seventh century, officials were selected by open civil service examinations and served as a countervailing force in relation to the power of the aristocrats. ${ }^{2}$ They played an important role in securing central authority within the empire. Apart from the imperial family and their servants (concubines and eunuchs), officials were the most important actors at court. But their sphere of activity was restricted to the outer spaces of the palace. They were frequently moved from posts in the central government at the capital to offices in the provincial administration. Membership in the outer court underwent frequent change and fluctuation. The emperor strengthened his authority by controlling the circulation of offices, merits, grants and information. In the sphere of the inner court, however, the personal composition was much more stable. Only members of the imperial family, concubines and eunuchs were admitted.

Emperors of both dynasties, Ming and Qing, safeguarded their positions as autocratic rulers by playing off the different groups. The Ming monarchs used eunuchs against the traditional bureaucratic literati elite, and the Qing emperors relied on Manchu and Mongol nobles as counterweights in the struggle for balance of power at court. On the Ming social scene, nobility, like most of the titles and ranks, had only been an ornament and had not counted as a factor in government. The Qing, in contrast, reintroduced the aristocratic element into court politics. If we want to understand the working of imperial authority at the peak of Chinese court society, we have to examine these different

\footnotetext{
${ }^{2}$ Benjamin A. Elman, 'Imperial Politics and Confucian Societies in Late Imperial China: The Hanlin and Donglin Academies', Modern China 15, 4 (1989) pp. 379-418, here p. 379.
} 
modes and methods of transgression between inner and outer spheres used by both dynasties of late imperial China. What role did the innerouter-court-dualism play in the late imperial era? What were the continuities in the Ming-Qing-transition, bracketing the two dynasties in a single period? In what ways did the Manchu monarchs alter the function of the palace system as the power base of imperial rule?

In agreement with $\mathrm{Wu}$ Han, the famous Chinese biographer of Taizu, ${ }^{3}$ Charles O. Hucker describes Taizu as the "bad first emperor of the worst sort", who cast his shadow over all of Ming history. ${ }^{4}$ This judgement is mainly based on Taizu's changes within the government system. Moreover, the context of the emergence of the dynasty is important. In a time of popular uprisings against the foreign rule of the Mongolian Yuan dynasty, Taizu had managed to rise from rebel leader to emperor. After his takeover, he regarded the reconstruction of the weakened state structure as his main task. In his combination of reconstruction and innovation, Taizu granted the emperor unprecedented preeminence.

In line with orthodox Confucian doctrine, Taizu created an image of the ruler fulfilling two complementary functions: As the autocratic head of state the emperor was personally responsible for devising effective means of controlling the world. In his role as teacher and reformer, he claimed, at the same time, supreme authority as the source of change and moral improvement. Thus, the first Ming monarch carried out two related reforms: He reemphasized the leading power role of the emperor and he reconfirmed society in the ancient moral and hierarchical norms. Taizu believed it was his mission to eliminate "barbarian" influences and to reconstruct the ideal Chinese world order. ${ }^{5}$ The introduction of a network of legal regulations and institutions reflected the emperor's desire to save the world through

\footnotetext{
${ }^{3}$ Wu Han, Zhu Yuanzhang zhuan [Biography of Zhu Yuanzhang] (Peking 1991) p. 301 .

${ }^{4}$ Charles O. Hucker, 'Ming Government', in: The Cambridge History of China, Volume 8: The Ming Dynasty, 1368-1644, Part 2, Denis Twitchett and Frederick W. Mote, eds. (Cambridge 1998) pp. 9-105, here p. 104.

${ }^{5}$ Edward L. Farmer, Zhu Yuanzhang and Early Ming Legislation: The Reordering of Chinese Society following the Era of Mongol Rule (Leiden; New York; Cologne 1995) pp. 18-32.
} 
comprehensive moral reform, to discipline his followers and to govern the realm.

In the scholarly literature, the Ming founder's reorganization of the central government is often labelled as the introduction of "Ming despotism". ${ }^{6}$ In fact, the Ming founder increased imperial authority to an unprecedented degree by restructuring government agencies. In 1380 , when the grand councillor $\mathrm{Hu}$ Weiyong was charged with plotting rebellion and was executed along with thousands of others, Taizu abolished the whole upper echelon of the central government ${ }^{7}$ and concentrated power securely in his own hands. ${ }^{8}$ This "decapitation" of the central bureaucracy represented a watershed in the Ming founder's assertion of his patrimonial prerogatives. ${ }^{9}$ No single appointee could gain overall control of the military, the general administration or the surveillance agencies, especially the censorate. The emperor was his own prime minister, took direct control of the six ministries and splintered the chief military commission into five coequal offices, each directly responsible to the throne. ${ }^{10} \mathrm{He}$ even fragmented censorial authority by placing it into the hands of low-ranking investigating censors, who answered directly to the ruler. ${ }^{11}$ Disciplinary problems within the bureaucracy were solved with ruthless brutality. Taizu justified his extremely contemptuous, distrustful and cruel behaviour towards his subordinates by citing his opposition to the mistreating of the common people by civil officials. ${ }^{12}$ The reorganization of government greatly increased the amount of work that fell to the emperor.

\footnotetext{
${ }^{6}$ Jiang Yonglin, The Great Ming Code/Da Ming lü (Seattle; London 2005) p. xxxvii.

7 The secretariat disappeared along with the tribunal of censors and the chief military commission. See John D. Langlois, Jr. 'The Hung-wu reign, 1368-1398', in: The Cambridge History of China, Volume 7: The Ming Dynasty, 1368-1644, Part I, Frederick W. Mote and Denis Twitchett, eds. (Cambridge 1988) pp. 107-181, here pp. 139-140.

${ }^{8}$ Charles O. Hucker, The Ming Dynasty: Its Origins and Evolving Institutions (Ann Arbor 1978) pp. 41-43.

9 Michael G. Chang, A Court on Horseback: Imperial Touring and the Construction of Qing Rule, 1680-1785 (Cambridge; London 2007) p. 15.

${ }_{10}$ These were the ministries of personnel, revenue, rites, war, justice and public work.

${ }^{11}$ Yonglin, Great Ming Code, pp. xxxvi-xxxvii.

12 John Dardess, Confucianism and Autocracy: Professional Elites in the Founding of the Ming Dynasty (Berkeley; Los Angeles; London 1983) p. 244. See also Wang Zhao, Zhongguo lidai zhongyang guanzhi shi [The bureaucratic system of the central government in Chinese History] (Shanghai 2005) p. 173; Hucker, 'Ming Government', p. 104).
} 
In 1385, Taizu stated that no ruler could fulfil his imperial Mandate of Heaven by simply radiating "mercy and virtue". In his institutional reorganisation, Taizu put into practice a model of rule already announced in 1377:

When the ruler, who settles a myriad of exigencies every day, becomes negligent, then everything comes to a standstill and endless disaster results. Ever since taking the throne I have forced myself to be diligent. I come to court before dawn and go back to the palace after dark. When I can't help sleep at night I get up and dress. Sometimes I scan the skies and take alarm if a star is out of place, and sometimes I ponder public matters, and if I find that something needs immediate action I make a written note of it so I can issue the appropriate orders at dawn. I would like to relax, of course, but I fear the Mandate of Heaven and have to do as I do. ${ }^{13}$

The official "Veritable Records of the Ming Dynasty" (Mingchao shilu) reported Taizu's work-load for an eight-day period in the fall of 1384 as covering 1,660 documents to which he gave his personal attention. ${ }^{14}$ For day-to-day administrative advice, the emperor continued to rely on scholar-advisors. In 1382, he established the position of grand secretary (da xueshi) to review state documents and to offer advice. The grand secretaries were chosen from the prestigious Hanlin Academy (Hanlin yuan) in the capital that had become a fully developed government institution and an important stepping-stone to political influence in the imperial court and state bureaucracy of the Ming state. ${ }^{15}$ Hanlin members served the emperor as private secretaries and consequently could rise easily to the pinnacles of power in the central bureaucracy as well as in the inner court. ${ }^{16}$ During the Ming dynasty, three out of four grand secretaries had earlier been members of the Hanlin Academy. ${ }^{17}$

As officials on call, the grand secretaries were stationed at various palaces in the Forbidden City and not clustered in one office. ${ }^{18}$ They

\footnotetext{
${ }_{13}$ Ming Taizu shilu [Veritable Records of Ming Taizu], Volume 5, p. 1882 (October 9, 1384), quoted in Dardess, Confucianism and Autocracy, p. 202.

${ }_{14}$ Ming Taizu shilu, [Veritable Records of Ming Taizu], Volume 6, pp. 2544-2545 (October 9, 1384).

${ }_{15}$ See Adam Yung-ch'eng Liu, The Hanlin Academy: Training Ground for the Ambitious, 1644-1850 (Hamden, CT 1981).

${ }^{16}$ Elman, 'Imperial Politics', p. 384.

${ }^{17}$ See Hung-Ting Ku, 'Upward career mobility patterns of high-ranking officials in Ch'ing China, 1730-1896', Papers on Far Eastern History 29 (1984) pp. 45-66.

${ }^{18}$ Langlois, 'The Hung-wu reign', pp. 148-149.
} 
were responsible for the coordination and supervision of the six ministries. Straddling the middle ground between outer and inner court, the Ministry of Rites (libu) became increasingly important. It was responsible for two major functions of government: education and foreign affairs. At the same time, it took care of imperial sacrifices and imperial family matters. It was the only ministry that was not only a full-fledged part of the outer court bureaucracy, but also an integral part of the inner court administration. Moreover, the Ministry of Rites served as a springboard for promotion to the Grand Secretariat. ${ }^{19}$

Not until the third Ming emperor, Chengzu (r. 1402-1424), was an "Inner Cabinet" (neike) formed to fill the gap between the throne and the imperial bureaucracy which had been created by the founding emperor when he had done away with the Central Secretariat (zhongshusheng) during the plot of 1380. In 1402, seven young officials were appointed to the Inner Cabinet, serving for many years, even after the end of the Chengzu reign. ${ }^{20}$ Under the guidance of an informally designated Senior Grand Secretary they developed collegial procedures. But their influence rested only on individual personality and therefore Grand Secretaries possessed weaker institutional foundations than the Grand Councillors of previous dynasties. Ming rulers formed very close relations with them, meeting them frequently in formal and informal settings. Chengzu even took some of his Grand Secretaries along on his field campaigns. Scholarly services like editing and compiling rather than administrative career paths led into the Inner Cabinet. Because Grand Secretaries were representatives of the inner court and without roots in the outer court, other officials of the central government in the outer court commonly associated them with the inner parts of the palace, consisting of palace women, eunuchs, imperial kinsmen and in-laws. From the point of view of the outer court officials, the Grand Secretaries were instruments of imperial authority and therefore represented a highly unwelcome, irregular intrusion between themselves and the emperor. The emperor for his part regarded his Grand Secretaries as important go-betweens. Their authority in either

\footnotetext{
${ }^{19} 66 \%$ of all Ming grand secretaries had also been members of this ministry. See Elman, 'Imperial Politics', p. 386.

${ }^{20}$ Hok-lam Chan, 'The Chien-wen, Yung-lo, Hung-hsi, and Hsüan-te Reigns, 18991435', in: The Cambridge History of China, Volume 7: The Ming Dynasty, 1368-1644, Part 1, Frederick W. Mote and Denis Twitchett, eds. (Cambridge 1988) pp. 182-304, here pp. 208-212.
} 
direction derived exclusively from their individual abilities and from the force of their personalities, not from their institutional role within imperial government. ${ }^{21}$ Actually, some of them even dared to contradict imperial decisions and to persuade the emperor to adopt different policy alternatives. ${ }^{22}$ The famous seventeenth century philosopher and Confucian scholar Huang Zongxi came to the conclusion:

It was not so clear whether [it] was a Liaison Office between the civil service and the throne, a command post over the ministries, merely an advisory agency, or even an arbitrating agency. ${ }^{23}$

The other significant institutional change under the third Ming emperor was the transfer of the imperial capital from Nanking to Peking, where his personal power base had been located as an imperial prince. The new palace city was completed in 1420. Also called the "Forbidden City" (zijin cheng), it symbolized two main characteristics of Ming rule: the distance of the monarchs from their subjects as well as the dominance of orders, prohibitions and other kinds of top-down-communication. The emergence of provincial governors, multi-province supreme commanders (zongdu) and the Inner Cabinet at court during the Chengzu reign indicated a kind of "relaxation" of the extreme centralization of power achieved under Taizu. ${ }^{24}$ This easing tendency continued under Chengzu's successors. Only strong rulers, however, could make any kind of centralized government work efficiently. Abilities of later Ming emperors inevitably fluctuated. They increasingly withdrew from their Grand Secretaries, and allowed other members of the court society to wield imperial authority. After the Tumu incident in 1449, when the emperor was taken prisoner during his campaign against Mongol tribes, Ming emperors became more and more passive and retreated into the inner court of the palace. Almost no audiences with ministers were held during seventy out of 137 years between 1465 and 1602. Messages were simply sent by eunuchs to the Secretariat's building. Moreover, after the death of Zhengde (r. 1505-1521) Ming rulers never left the Forbidden City. From the mid-fifteenth century,

\footnotetext{
${ }^{21}$ Hucker, The Ming Dynasty, p. 91.

${ }^{22}$ Zhang Jinfan, Zhongguo guanzhi tongshi [A Complete History of the Chinese bureaucratic system] (Beijing 1992) pp. 503-504.

${ }^{23}$ Cited in W.T. de Bary, 'Chinese Despotism and the Confucian Ideal: A Seventeenth-Century View', in: Chinese Thought and Institutions, John K. Fairbank, ed. (Chicago 1957) p. 175.

${ }^{24}$ Hucker, The Ming Dynasty, p. 73.
} 
the last indigenous government in China seemed to be without imperial direction at all.

Imperial affairs were conducted mainly through eunuchs, whose actions often provoked factional disputes at court that seriously disrupted governance. Eunuchs had been part of all imperial courts in Chinese history. ${ }^{25}$ They were a sumptuary privilege reserved to royalty. No one else in Chinese society was allowed to employ them. In 1367, Taizu established a bureau for eunuchs. Later he reorganized it in twelve functionally distinct supervisory offices handling services needed within the inner court and gradually displacing palace women in many of those roles. After his coup d'état, the third emperor Chengzu founded the first regular training school for eunuchs. He had to rely on them, because the court ministers opposed his usurpation of the throne and remained loyal to his nephew, the Jianwen Emperor (r. 1398-1402). ${ }^{26}$

Literacy changed eunuchs into a dominant group in court society to be reckoned with. A eunuch bureaucracy, consisting of all twentyfour offices, emerged with its own ministry of personnel, called the Directorate of Palace Eunuchs (neiguanjian). Despite Taizu's intention to reduce eunuch staff to no more than one hundred persons, their numbers increased constantly to about seventy thousand by the end of the dynasty. ${ }^{27}$ Eunuch bureaucrats were ranked and paid on the model of officialdom though their salaries were minuscule. As extensions of the ruler's person, eunuchs could wield great power that civil officials could not aspire to. As members of the imperial bodyguard, they formed the core of the emperor's private machinery of surveillance. ${ }^{28}$ They ran the entire imperial household and took control of all official communication. In the imperial household, only one agency was left in female responsibility. ${ }^{29}$ Matters such as foodstuffs, ritual regalia, ceremonies, utensils, document handling, seals, and staff surveillance were all arranged by eunuchs. They maintained the palace treasury and

${ }^{25}$ Yuan Lükun and Wei Jianqin, Taijian shihua [A History of Eunuchs] (Zhengzhou 1984) pp. 1-15. See also Henry Shih-shan Tsai, The Eunuchs of the Ming Dynasty (Albany, NY 1996).

${ }_{26}$ Tsai, Eunuchs of the Ming Dynasty, p. 13.

${ }_{27}$ Hucker, The Ming Dynasty, p. 93. Shih-shan Henry Tsai estimated their number even to 100.000 persons. See Tsai, Eunuchs of the Ming Dynasty, p. 11.

${ }^{28}$ Frederick W. Mote, Imperial China, 900-1800 (Cambridge, Mass. 1999) pp. 602-605.

${ }_{29}$ Hucker, The Ming Dynasty, p. 71. 
served in the imperial secret service. Granted the right to memorialize the emperor directly, they could act in total separation from the institutions of the outer court, where their influence also grew. ${ }^{30}$

Eunuch power penetrated into the outer court domain by the way of the Civil Documentation Bureau (wenshufang), staffed by ten eunuchs, who officially registered all incoming documents and all outgoing imperial comments or instructions. They functioned as mediators between the emperor and the Grand Secretaries, who rarely had personal contact with the emperor on a daily basis. ${ }^{31}$ From the midfifteenth century, when Ming rulers increasingly paid more attention to personal affairs than to state matters, eunuchs of the Civil Documentation Bureau also inserted their own ideas into the documents before passing them from the Inner Cabinet to the throne. If Grand Secretaries learned how to cooperate closely with their eunuch counterparts, some sort of balance was possible in the Ming court polity. As imperial special agents, eunuchs were also sent on diplomatic missions. They exercised military functions by commanding armies and navies, and they supervised tax collections. ${ }^{32}$ Under weak emperors some senior eunuchs became extremely influential, controlling the government as "eunuch dictators" ${ }^{33}$ In such cases, the ongoing tension between the "irregular" eunuch bureaucracy and the proper court administration of the officials reached destructive heights.

During the late Ming period the bureaucracy was increasingly driven by cliques, factions, and personal antagonisms and unable to generate a coherent policy. After the death of the Wanli-Emperor (r. 1602-1620), a faction of ultra-puritanical Confucian scholars and ex-officials, who were loosely connected through the private Donglin Academy in the Yangzi delta, infiltrated the central bureaucracy in order to attack the young emperor's favourite, the illiterate, but influential eunuch Wei Zhongxian (1568-1628). ${ }^{34}$ The power vacuum at the imperial centre was filled by contending eunuchs and gentry-official groups, who each

${ }^{30}$ Robert B. Crawford, 'Eunuch Power in the Ming Dynasty', T'oung Pao 49 (1961) pp. 115-148, here p. 135.

${ }_{31}$ Tsai, Eunuchs of the Ming Dynasty, p. 226.

32 Tsai, Eunuchs of the Ming Dynasty, pp. 14-17, 135-164.

${ }^{33}$ Charles O. Hucker, 'Government and Organisation of the Ming Dynasty', Harvard Journal of Asiatic Studies 21 (1958) pp. 1-66, here p. 11.

${ }^{34}$ See in detail John E. Dardess, Blood History in China: The Donglin Faction and Its Repression, 1620-1627 (Honolulu 2002). 
sought control of the inner court. ${ }^{35}$ During Wei Zhongxian's counterattack the Donglin faction was almost destroyed. ${ }^{36}$ The political atmosphere of the late Ming period discouraged many scholar-officials from seeking central government employment at all. They preferred congenial environments in the provinces and devoted their energies to a more scholarly spiritual life. ${ }^{37}$ After Wei Zhongxian's death, the emperor ordered a purge within the government: 260 leading collaborators were named by the emperor's inner court assistants and subsequently punished. But these actions failed to restore dynastic vigour. Imperial failure, peasant rebellion and Manchu intervention finally destroyed the last Han-Chinese dynasty in history. ${ }^{38}$

The Qing dynasty created one of the largest and longest-lived multiethnic empires of the early modern world. To win the allegiance of the different ethnic groups they ruled, the Manchu deployed the various rhetorical resources they had acquired during their rise to the Chinese throne. They simultaneously embodied crucial elements of the political traditions of the several peoples. Qing emperorship can be described as "simultaneous expressions in multiple cultural frames." 39 The "sinicization" of Manchu rule in China reflected the need of early Qing monarchs to appeal ideologically to the traditional Chinese elite. NeoConfucianism served as a source of rhetoric for the Manchu court as it struggled to find a language to win over the Confucian literati. ${ }^{40}$ To meet the needs of the Inner Asian peoples of their empire, the Manchu added a Court of Colonial Affairs (Lifanyuan) to the Chinese central government. The Lifanyuan was the institutional tool to transform Inner Asian peoples into subjects of the Qing empire without making them Chinese. Together with the six ministries and the Censorate (duchayuan) it belonged to the eight most important governmental offices situated in the outer court of the palace. The difference between

35 Elman, 'Imperial Politics,' p. 389.

36 Elman, 'Imperial Politics,' p. 395.

37 Mote, Imperial China, p. 770.

38 See Mote, Imperial China, pp. 781-783.

39 Pamela Crossley, A Translucent Mirror: History and Identity in Qing Imperial Ideology (Berkeley; Los Angeles 1999) p. 1.

${ }^{40}$ Crossley, A Translucent Mirror, pp. 226-232. 
the various ethnic groups of the empire was formalized and reified. Their myths of descent and lineage histories were systematically documented. In this way, Manchu rulers were able to be all things to all people. As Qing emperors performed their different ritual obligations, they imagined themselves as embodying the roles they were playing. ${ }^{41}$ To clarify cultural differences and to prove subsequently the universal competence of the ruler was the "mission" of Qing emperors. ${ }^{42}$

At the same time, the Manchu monarchs as north-easterners were very conscious of their historical, cultural and linguistic separation from the Chinese speakers to the south. Like earlier non-Han conquest regimes from the tenth to the fourteenth century, the Manchu maintained their separate identity. ${ }^{43}$ The ruling formation of the Qing court marked itself off from those it ruled by certain religious, linguistic, ritual and social characteristics, all manifested by the imperial household. ${ }^{44}$ Manchu customs and practices survived through their imbrication in specifically Manchu institutions, especially the banner system. ${ }^{45}$ The Qing was a conquest dynasty and it remained organized like a "nation at arms" during the entire period of its rule in China.

The military system of banners had already been established in 1601 to break down traditional tribal divisions. Manchu soldiers and their families were organized into eight fighting groups, distinguished in formation by flags of different colour. ${ }^{46}$ Gradually by accretion eight Chinese and eight Mongol banners were organized. The banner elite was graded into ranks of varying nobility. After 1644, the banners represented the main military force of Qing China. They were stationed in the capital and throughout the empire, receiving for their support tracts of land surrounding the capital. ${ }^{47}$ The traditional Chinese troops

${ }^{41}$ Angela Zito, Of Body and Brush: Grand Sacrifice as Text/Performance in Eighteenth-Century China (Chicago 1997) p. 210.

${ }_{42}$ Crossely, A Translucent Mirror, p. 270.

${ }^{43}$ Eveleyn S. Rawski, 'The 'Prosperous Age': China in the Kangxi, Yongzheng and Qianlong Reigns', in: China: The Three Emperors, 1662-1795, Evelyn S. Rawski and Jessica Rawson, eds. (London 2005) pp. 22-40, here pp. 22-23.

${ }^{44}$ Evelyn Rawski, The Last Emperors: A Social History of Qing Imperial Institutions (Berkeley, CA 1998) p. 9, pp. 29-55.

${ }_{45}$ Mark C. Elliott, The Manchu Way: The Eight Banners and Ethnic Identity in Late Imperial China (Stanford, CA 2001) p. 12.

${ }_{46}$ Wang Jingze, Qingchao kaiguo shiqi baqi yanjiu [The Eight Banners at the beginning of the Qing Dynasty] (Changchun 2002) pp. 8-51.

${ }_{47}$ Ding Yizhuang, Qingdai baqi zhufang yanjiu [The Garnisons of the Qing Eight Banners] (Shenyang 2002) pp. 117-189. 
of the Green Standards (lüying) were reduced to gendarmerie forces. In the capital, bannermen were organized in outer and inner banner divisions, the latter responsible for protecting the imperial palace. Only members from the three superior banners of the inner banner divisions were chosen as imperial bodyguards, who had access to the inner court. Bannermen enjoyed a highly privileged status. The inner city of Peking was reserved for them, where there were special quarters for bannermen and their families to live in accordance with the colours assigned to the different banner divisions. ${ }^{48}$ Bannermen took for themselves never less than one half of the key posts in the imperial bureaucracy. A separate system of military examinations was maintained for them. They filled both military and civil positions provided for them in the Qing institutional hierarchy. Intermarriage with Han-Chinese was prohibited for the elite of Manchu, Mongol and Chinese banner forces. A form of political endogamy excluded ties between the ruling house and the Chinese bureaucrats. ${ }^{49}$ Bannermen formed a hereditary warrior caste, alimented by the state. Their residence, livelihood, training, and status in China were all arranged by the dynasty. The mutual support of imperial house and the banner community reinforced their sense of common destiny. ${ }^{50}$

In the early eighteenth century, the banner order underwent a process of bureaucratization. A routine procedure for the evaluation and promotion of banner personnel developed, and bannermen made their way into the civilian administration. ${ }^{51}$ Half of the presidencies of the six boards were reserved for them and most of the governors-general came from the banner nobility. What made them unique in the early modern world was their extraordinary loyalty to the ruling house. Banner armies never turned on the court that had created them. Instead, bannermen evolved into one of the longest-lived and most loyal service elites in history. ${ }^{52}$ Though officials of the banner institutions were

${ }^{48}$ Rawski, The Last Emperors, pp. 26-27.

49 Evelyn S. Rawski, 'Ch'ing Imperial Marriage and Problems of Rulership', in: Marriage and Inequality in Chinese Society, Rubie S. Watson and Patricia Buckley Ebrey, eds. (Berkeley, CA 1991) p. 170.

${ }^{50}$ For examining the special status of the Eight Banners in Qing dynasty see Elliott, The Manchu Way, especially pp. 133-174.

51 Elliott, The Manchu Way, pp. 203-205. See also Pamela K. Crossley, 'Manchu Education', in: Education and Society in Late Imperial China, 1600-1900, Benjamin A. Elman and Alexander Woodside, eds. (Berkeley, CA 1994) pp. 340-378.

${ }^{52}$ R. Kent Guy, 'Who were the Manchus? A Review Essay', Journal of Asian Studies 61 (2002) pp. 151-164, here p. 152. 
responsible for less than two percent of the population, banner officialdom became the biggest subsection of the Qing bureaucracy. While the Han-Chinese population was administered according to traditional Chinese methods, the banner people were subjected to a kind of micromanagement by the Qing court: Births, deaths, marriage, employment, retirement, and residence were all monitored by triennial censuses. Of all imperial institutions, only banners had their own, exclusive administrative handbook, the "Comprehensive History of the Eight Banners" (Baqi tongzhi), first published in 1739. The selection of banner officials and officers was a prerogative of the emperor. ${ }^{53}$ Banners never entirely escaped their fragmented origins as a tribal organization. There was no central banner board, which would have made them independent from the traditional Chinese outer court government.

In the emperor's eyes, his imperial guards (shiwei) constituted an alternative tool of imperial will to the civil service bureaucracy of the Han-Chinese elite, and thus enhanced the ruler's flexibility. They were visible, prestigious elite units responsible for the security of the monarch. Their special status was signalled by their garments, peacock feathers and bright yellow riding jackets, setting them apart and nurturing a corporate solidarity. They fulfilled a wide variety of tasks. Their chamberlains even enjoyed the same top status in the ranking hierarchy as the sons of princes. Moreover, for the banner nobility, the imperial guards represented a channel of upward mobility at the Qing court. ${ }^{54}$

The court nobility was another new element introduced by the Qing to intertwine inner and outer court responsibilities. Under the Ming, the imperial family had been the only group of nobles with influence in the government and only the Heir Apparent (taizi), usually the eldest son, was allowed to reside in the imperial palace at the capital. All other sons received territorial titles and lived in princely establishments (wangfu) throughout the empire. They were salaried dignitaries and no more. Though noble titles were also granted to relatives by marriage of the emperors, they mostly were prevented from taking any part in routine administration..$^{55}$ Instead, the Qing styled all brothers and sons of emperors as imperial princes (qinwang), moulding them

${ }^{53}$ Elliott, The Manchu Way, pp. 135-134.

${ }_{54}$ Rawski, The Last Emperors, pp. 82-87.

${ }^{55}$ Hucker, 'Government and Organisation of the Ming Dynasty', pp. 9-10. 
into a kind of ruling kin-coalition. The Ming system of primogeniture was replaced by choosing the best-suited prince as heir and keeping his name secret until his accession. ${ }^{56}$ Sons of all consorts were made eligible to become emperor. The delayed designation of the heir triggered intensive succession struggles, which could expand even into the outer court realm. Qing imperial sons were not barred from political participation. Rather, they were expected to carry out ritual, military, and diplomatic tasks. The co-residence of all imperial princes in the palace strengthened familial sentiments and allowed the emperor to control his sons' activities and to evaluate their personalities and talents. In this way, the throne could assess their fitness by their performance. ${ }^{57}$

Though favoured dignitaries and new members of the imperial family were all ennobled, they never were granted territorial fiefs and they were not required to live away from the capital as during the Ming period. The first actual Qing ruler, Prince Dorgon (1612-1650), a younger brother of Huang Taiji, is an early example of this strategy. As regent for the Shunzhi Emperor (r. 1644-1661), he governed China until his death. ${ }^{58}$ Imperial princes headed the five lesser banners that complemented the three upper banners under direct command of the emperor. In 1723, the Yongzheng Emperor even decided to appoint imperial princes to the ministries of revenue, works and rites. ${ }^{59}$ His son Qianlong ordered the construction of 360 additional rooms for royal princes in the Forbidden City. ${ }^{60}$ Manchu tribal leaders, Mongol rulers, early Chinese collaborators and generals were rewarded for their support with career opportunities for their sons and with wives from the imperial lineage. ${ }^{61}$ Such marriage arrangements functioned as

\footnotetext{
${ }^{56}$ Huang Pei, Autocracy at Work: A Study of the Yung-cheng Period, 1723-1735 (Bloomington 1974) pp. 95-96.

${ }^{57}$ Rawski, 'Ch'ing Imperial Marriage', p. 172.

${ }^{58}$ Jin Xingyao, Qingdai Gongting zhengbian jiyao [Political Changes at the Qing Court] (Xi'an 2005) pp. 62-68; Wan Yi, Wang Shuxiang and Liu Yao, Qingdai gongting $s h i$ [History of the Palace in Qing times] (Shenyang 1990) pp. 25-34.

${ }_{59}$ Zhang, Zhongguo guanzhi tongshi, 650.

${ }^{60}$ Qin Guojing, 'Lun Qianlong huangdi zhili gongting de gongze' [Merits of the Qianlong emperor in governing the palace], in: Qingdai gongshi luncong, ed Qingdai gongshi yanjiuhui, (Beijing 2001) pp. 1-11, here 5.

${ }_{61}$ The privilege of receiving official posts without entering the difficult state examinations for sons of government officials already existed under former dynasties. The Qing government used it to elevate their bannerrmen and Mongolian allies. For the Qing bureaucratic system in detail see Ai Yongming, Qingchao wenguan zhidu [The civil service system of the Qing dynasty] (Beijing 2003).
} 
important means of winning new allies and of stabilizing coalitions at court and throughout the expanding Qing empire. ${ }^{62}$

Etiquette, ranks and ceremonies served as important instruments of communication and control for the Qing rulers. During the conquest era, the "courtization" of Manchu warriors was realized through the transformation of military titles into titles of nobility. A system of hereditary titles with 27 separate ranks was devised giving rise to a highly stratified court aristocracy. According to their self-image as rulers of a multiethnic empire, the Qing integrated peoples of the Inner Asian regions as major actors into their imperial enterprise. As subjects of the Qing state they were on equal footing with the Han Chinese of China proper. Manchu emperors aimed at the coexistence of diverse cultures within the loose framework of their personalistic rule. They adopted a policy of residential, administrative and institutional segregation to perpetuate the separate identities of the various peoples. To redefine the political, economic and cultural relationships between China proper and Inner Asia, the Qing court set up the imperial rituals of pilgrimage to the emperor (chaojin), imperial hunt (weilie) and tribute (chaogong), which were all organized and controlled by the Lifanyuan. ${ }^{63}$ Inner Asian nobles were divided into rotas for annual journeys to the Qing emperor. At the summer palace in Chengde they had to perform rituals of submission, the chaojin. The imperial hunt at Mulan was another court ritual designed for the Inner Asian subjects of the Qing throne. Celebrations of the emperor's birthdays with magnificent banquets and entertainments were used to demonstrate the glory and generosity of the monarchy. In this way, previously independent and often rebellious Inner Asian nobles were tamed and "domesticated" at the Manchu court. Court rituals, in general, were used by Qing monarchs as instruments of power. At the same time, they limited their own freedom as the emperors became enmeshed in a self-created web of symbols, rules and obligations.

Unlike their European counterparts, the Qing peers constituted a service nobility, whose power derived entirely from the monarch. During the succession of infant emperors in the late nineteenth century, imperial agnates even played a leading role in national politics. Prince

${ }^{62}$ Cui Mingde, Zhongguo gudai heqin shi [The History of Marriage Alliance in Traditional China] (Beijing 2005) pp. 475-513.

${ }^{63}$ Ning Xia, 'The Lifanyuan and the Inner Asian Rituals in the Early Qing (16441795)', Late Imperial China 14 (1993) pp. 60-92, here p. 61. 
Gong (1833-1899), son of the Daoguang emperor (r. 1821-1850), negotiated with the foreign powers in 1860 after the second Opium War, when his half brother, the Xianfeng emperor (r. 1851-1861), had fled Peking. Of the four adjutants-general protecting the capital in the late Xianfeng reign, three were imperial agnates and the fourth an imperial affine. ${ }^{64}$ At the Qing court a "lean aristocracy" was available to exercise a wide variety of political and military functions. ${ }^{65}$ Like the bannermen the imperial nobility turned into a useful instrument for influencing outer court policy from within inner court domains. Both groups, seen within the overall configuration of the imperial court, were a genuine Manchu contribution to the history of governance in China.

A third group at the Qing court with a special role and status were the bondservants (baoyi). They represented a different class of imperial household servants and replaced the Ming eunuchs in the management of the emperor's domestic affairs. In comparison with previous Chinese dynasties, the Manchu government was relatively free from eunuch abuses. The Imperial Household (neiwufu) staffed mainly by bondservants, played an important role in government and society, controlling all activities within the palace establishment and the aggregated 56 service agencies. ${ }^{66}$ Many of its departments resembled organs of the official bureaucracy, acting as functional equivalents of the six ministries and the censorial office. Starting with a staff of 400 members, the Imperial Household grew to over 1,600 members by the end of the eighteenth century, most of them imperial bondservants. ${ }^{67}$

Qing bondservants were often former prisoners-of-war and their descendants. They were drawn from the three upper banners under the direct command of the emperor. Similar to eunuchs or householdslaves, they were entirely dependent on the monarch's personal will. The position of an imperial baoyi at court could lead to a remunera-

64 Rawski, The Last Emperors, p. 196.

65 Rawski, The Last Emperors, pp. 77-80, 91-93.

66 The Imperial Household Department had to feed, clothe, and house the monarch, provide him with entertainment such as libraries, theatrical performances and the harem of palace women. The administration of the three upper banners, the imperial estates and of the commercial enterprises throughout the empire was also assigned to this institution. The Department derived revenue directly from the imperial estates in Manchuria and around Peking, from ginseng trade and other commercial operations, from collection of customs revenue and foreign tribute, from loans to merchants and from expropriation of private property.

${ }^{67}$ Qi Meijin, Qingdai neiwufu [The Department for Internal Matters of the Qing Period] (Beijing 1998) pp. 276-280. 
tive career. After attending special schools under the Manchu banner system, the hereditary bondservants entered the Imperial Household as junior clerks. They were promoted by seniority within its extensive and elaborate bureaucracy. Top posts were only given to personal favourites of the emperor. ${ }^{68}$ Moreover, the monarchs placed trusted bondservants (baoyi) in key positions in various government commissions and departments that were in charge of the extensive public economic organisations, thus transcending the boundaries of the inner domain. The network of bondservants throughout the empire provided the emperor with money, information and critical reports on the work of the regular bureaucrats, functioning as a parallel bureaucracy to the official one. ${ }^{69}$

In general, the Qing dynasty did not simply take over the Ming apparatus of government in its entirety, but restructured the governmental system, infused new energy into it and made it work more efficiently than ever before. While the traditional division in six ministries survived, these institutions lost the authority they had in Ming times. Ministers could no longer issue direct orders to provincial governors, and the lines of communication between them were often hopelessly entangled. Vice ministers were now allowed to send their own memorials, dispersing authority within a single institution. Everyone was now directly responsible to the monarch. ${ }^{70}$ But just as in the Ming period, only strong rulers succeeded in using these opportunities to enhance autocratic power. In Qing China, only the three emperors of the High Qing period-Kangxi (r. 1662-1722), Yongzheng (r. 1723-1735) and Qianlong (r. 1736-1796)-demonstrated such personal qualities. All three were workaholics, who rose before five o'clock every morning to read memorials and who handled several hundred items a day. They also invented new instruments to strengthen imperial leverage. ${ }^{71}$

One of them was the system of secret palace memorials (zhupi zouzhe). An autonomous circuit of information-inflow and decision-making was created to bypass the Grand Secretariat, the official guardian of

\footnotetext{
${ }^{68}$ Preston M. Torbert, The Ch'ing Imperial Household Department: A Study of its Organisation and Principal Functions (Cambridge, Mass. 1977) pp. 60-78, 175-182.

${ }_{69}$ Jonathan D. Spence, Ts'ao Yin and the K'ang-his Emperor. Bondservant and Master (New Haven 1966) pp. 7-17.

${ }^{70}$ Zhao, Zhongguo lidai zhongyang guanzhi shi, pp. 267-269.

${ }^{71}$ About the Kangxi-Emperor it is said, that he managed as many as 700-800 items of business in one day. See Jonathan D. Spence, Emperor of China: Self-Portrait of K'ang-hsi (London 1974) pp. 54-56.
} 
transmission. This system was created by Kangxi when he used Manchu officials to keep him apprised of developments in the palace and in the capital. ${ }^{72}$ The emperor was beset by intrigues from competing princes in the heir-apparent crisis and he asked selected officials, often members of the Imperial Household on secondment to provincial posts, to report to him secretly. ${ }^{73}$ These letters were sent by private couriers in a box to which only the sender and the emperor held keys. ${ }^{74}$ During the 1690s, he extended this system to include regular field-officials. After deposing the heir-apparent in 1712, Kangxi ordered all court officials of the third grade upwards to provide him with such secret memorials..$^{75}$ The flow of secret information to the emperor weakened the influence of the outer court bureaucracy. Imperial bondservants in the provinces, nobles and officials in the capital regularly submitted secret reports to the emperor, bypassing the transmission of routine memorials through the Grand Secretariat, which was thereby demoted to an impotent secretarial office. ${ }^{76}$

The influence of the Grand Secretariat was further weakened by the Southern Study (nanshufang), which had originally been created in 1659 by the Kangxi emperor to supply him with intellectual resources when he retired to the private quarters of the palace. Later it was also used for imperial pronouncements. ${ }^{77}$ Members of the Hanlin Academy were appointed into this inner court agency as writers, calligraphers and copyists. Because most of them were Han-Chinese, the nanshufang was used as a liaison office to the traditional Confucian elite. ${ }^{78}$ The court supported Confucianism as cultural code for the administration of its Chinese-speaking subjects. From the Yongzheng reign on, the

${ }_{72}$ Elliott, The Manchu Way, p. 60.

${ }^{73}$ Yang Qiqiao, Yongzheng di jiqi mizhe zhidu yanjiu [The Yongzheng emperor and his system of secret palace memorials] (Shanghai 2003) pp. 157-158.

${ }^{74}$ Mark C. Elliott, 'The Manchu-Language Archives of the Qing Dynasty and the Origin of the Palace Memorial System', Late Imperial China 22 (June 2001) pp. 1-70, here pp. $49-56$.

${ }^{75}$ See Silas Wu, Communication and Imperial Control in China-The Evolution of the Palace Memorial System, 1693-1735 (Cambridge, Mass. 1970).

${ }^{76}$ Elliott, The Manchu Way, pp. 46-47.

77 Jinfan, Zhongguo guanzhi tongshi, p. 619.

${ }^{78}$ Zhu Jinpu, 'Lun Kangxi shiqi de nanshu fang' [The Southern Study during the Kangxi period], in: Qingdai gongshi yanjiuhui [Research association for Qing palace history], ed. Qingdai gongshi tanwei [Researches on Qing palace history] (Beijing 1991) pp. 1-24, here p. 1. 
numbers of Hanlin members were reduced while their status increased. They often received simultaneously appointments as ministers. ${ }^{79}$

The most important institutional invention at the Qing court was the Grand Council (junjichu, lit. "Office of Military Plans"). By its very existence, it weakened the outer court bureaucracy in favour of emperor's inner circle superseding the Grand Secretariat as the centre of decision-making. The Grand Council was originally set up by Yongzheng as a cabinet of trusted advisers to handle military campaigns. ${ }^{80}$ This highly confidential group met in a small building on the borderline between the inner and outer court parts of the palace. Like other inner court agencies it was exempted from censorate control. ${ }^{81}$ Always headed by an imperial prince, its usually six members changed frequently until the nineteenth century. They were chosen from among the heads and deputy heads of the Six Ministries, the Grand Secretariats, and sometimes from its own thirty-two senior secretaries. The Grand Ministers of the State met daily with the emperor and countersigned all documents in his name. They held their positions concurrently with their civil service ones. The result was an overlap between the Grand Secretariat, the Six Ministries and the Grand Council. This combination of concurrent posts and a large loyal body of former clerks gave the Grand Council valuable contacts throughout the capital and the provincial bureaucracy.

On a long-term basis, the mixing of Manchu and Chinese in the empire's top ruling body contributed to the reduction of old Manchu princely and grandee preponderance at court and allowed new scope for the influence of Chinese officials on policymaking. Moreover, the creation of the Grand Council made it possible to run the government effectively even if no strong monarch prevailed at court. In the late nineteenth century, in a period of infant and debilitated emperors, the dependence on the Grand Councillors in the running of state affairs to

\footnotetext{
${ }^{79}$ Zhang Deze, Qingdai guojia jiguan kaolue [State institutions during the Qing period] (Beijing 2001) p. 154.

${ }^{80}$ Zhao, Zhongguo lidai zhongyang guanzhi shi, p. 176; Bao Jingsheng, 'Junjichu yu Qingdai huangquan' [The Council of State and imperial authority in the Qing period], in: Ming Qing luncong [A Collection of Essays on the Ming and Qing Dynasties], Zhu Chengru and Wang Tianyou, eds. (Beijing 2005) pp. 257-267, here p. 257.

${ }^{81}$ Bo Zheng, Zhongguo gudai guanzhi [The Bureaucratic System in Ancient China] (Beijing 1989) p. 133. According to Wang Zhao it was no regular state institution or independent office, but a private organ of the emperor. See Zhao, Zhongguo lidai zhongyang guanzhi shi, p. 177.
} 
some extent compensated for the weakness at the imperial centre and thus prolonged the life of the Qing dynasty. ${ }^{82}$

From the tenth century, the power of Chinese emperors increased by a continuous process of institutional evolution reaching its zenith in late imperial times. Though the form of the two dynastic systems was different, emperors of both dynasties tried to strengthen their autocratic position not only through reforms of the central government in the outer court part of their palace, but also through an intertwining of inner and outer court realms. Social groups from the inner court were mobilized and their new functions institutionalized. At the Ming court, Grand Secretaries furthered the integration of the imperial administration; eunuchs acted as the monarch's eyes, ears, and arms. Under the third Ming emperor Chengzu both groups received their own agencies within the palace administration becoming a kind of "buffer" between the emperor and his outer court central government. ${ }^{83}$ Eunuchs like their rivals in the Grand Secretariat acted mainly through factions within the court system. Therefore, only strong emperors could use them effectively in the power struggles between the inner court, the emperor's faction, and the outer court, which was identical with the official literati faction.

Qing emperors demonstrated an even more casual attitude towards the traditional division between inner and outer court by moving the high-level decision-making of the central government to their private quarters in the inner court. ${ }^{84}$ Admission into the inner court was strictly limited to a select "inner circle", mostly members of the Manchu elite, at the expense of the Han-Chinese bureaucracy. Routine government business was increasingly located within the inner court. ${ }^{85}$ The confidential system of palace memorials increased the monarch's ability to

\footnotetext{
${ }^{82}$ See Beatrice S. Bartlett, Monarchs and Ministers: The Grand Council in MidCh'ing China, 1723-1820 (Berkeley 1991) pp. 257-278.

${ }^{83}$ Hucker, The Ming Dynasty, p. 95.

${ }^{84} \mathrm{Liu} \mathrm{Lu}$, 'The Forbidden City during the Qianlong reign', in: The Qianlong Emperor: Treasures from the Forbidden City, Zhang Hongxing, ed. (Edinburgh 2002) pp. 151-155, here p. 154.

${ }_{85}$ See Bartlett, Monarchs and Ministers, pp. 13-64.
} 


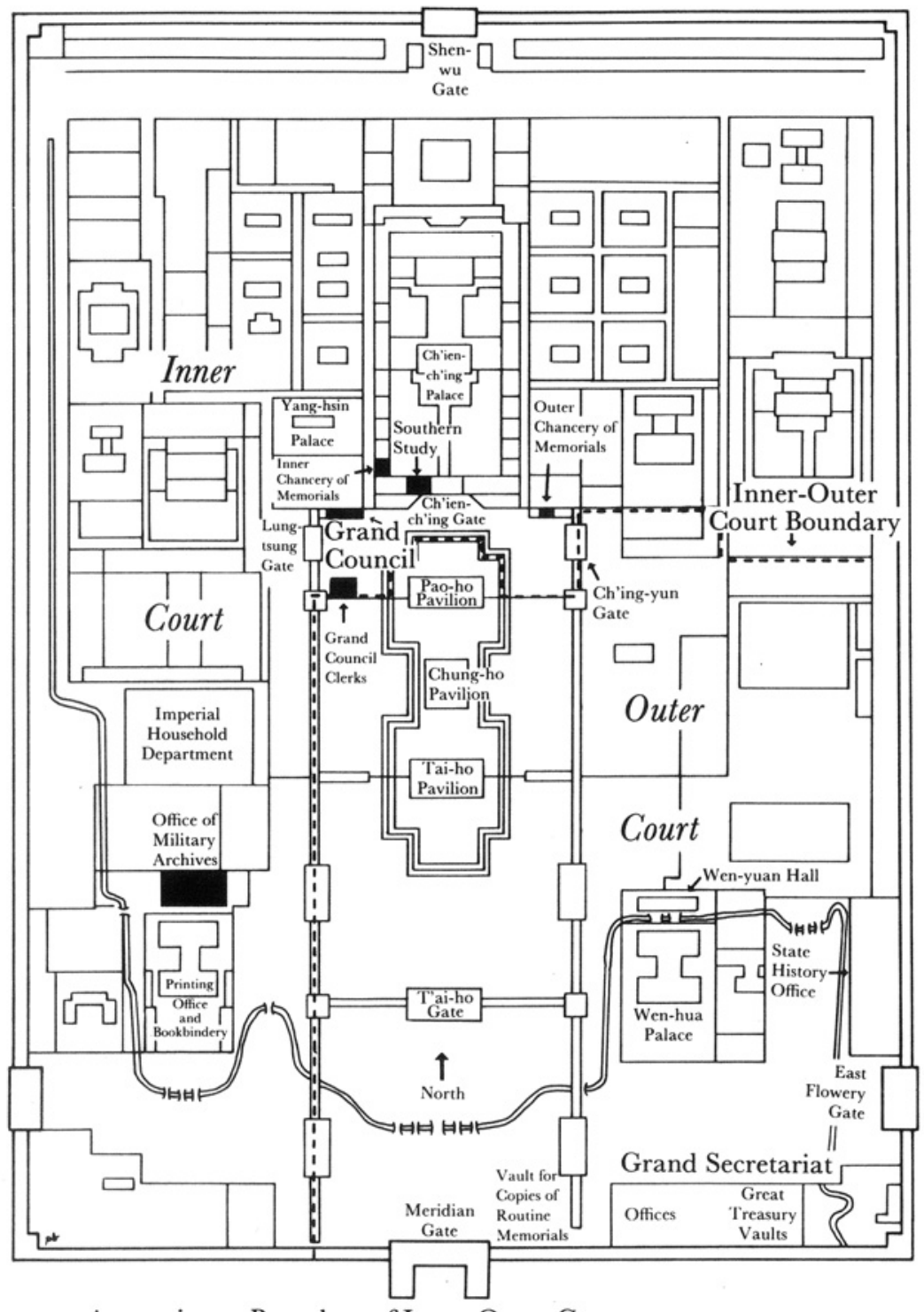

- - - - Approximate Boundary of Inner-Outer Court

Figure 1. Inner and outer court: the Forbidden City in the 17th and 18th centuries (from: Beatrice S. Bartlett, Monarchs and Ministers. The Grand Council in Mid-Ch'ing China, 1723-1820 (Berkeley 1991) p. 14). 
acquire sensitive intelligence about outer court and provincial officials and to maintain the throne's dominance over its civil service.

Similar to the Ming eunuchs, bondservants functioned as new informal channels for controlling court politics as long as strong emperors were able to pull these strings. Young or weak rulers easily fell victim to such networks of communication. Compared to the Ming eunuchs, Qing bondservants lacked military power as well as the ability to control decision-making processes at court, but their economic status often corresponded to the eunuch supervision of imperial manufactories and customs bureaus. In both cases, the power derived from direct imperial grants and by-passed the regular bureaucracy. The bondservants represented a new type of informal agents of autocratic rule. They often misused the authority granted to them and contributed to the economic, social and political crisis of their time. ${ }^{86}$ The balance-ofpower system at court, as described by Norbert Elias, depended on the constant intervention of the emperor himself. He could safeguard his position only by playing off members of the upper strata within court society against each other, if he was really strong enough to maintain himself as the remote arbiter. ${ }^{87}$

Sociological models like Norbert Elias's "court society" expose some characteristics of the late imperial court in China. Multiple roles of the respective monarchs are thrown into sharper relief. The personality of individual emperors mattered a great deal. But to some extent they were prisoners of the very system they had helped to create. A further question to be addressed in terms of the model might be the declining effectiveness of court mechanisms after the Qianlong period.

The creation of a Sino-Manchu empire as some kind of precursor to the multiethnic nation state of the twentieth century was never the Qing rulers' political goal. Comparable to the absolute monarchy of the French king Louis XIV, the Qing empire was no planned project realized by exceptional individual personalities. Even strong Qing emperors like Kangxi or Qianlong had to come to terms with other social groups in the network of court society. The figuration model of Elias can help to explain how monarchs developed a system of checks and balances at court and in society at large in order to sepa-

\footnotetext{
${ }^{86}$ Torbert, The Ch'ing Imperial Household Department, pp. 181-182.

${ }^{87}$ Norbert Elias, Die höfische Gesellschaft. Untersuchung zur Soziologie des Königtums und der höfischen Aristokratie (Frankfurt a.M. 1989) p. 254.
} 
rate the conquerors from the conquered while achieving a degree of institutional integration indispensable for the government of the most populous country in the world. The institutionalization and bureaucratization of the autocratic court was meant to give duration to imperial government, prevent arbitrariness of individual and collective action and make the future as predictable as possible. ${ }^{88}$ The new institutions created new channels of court policy and influenced different groups of court society. ${ }^{89}$ Imperial power was strengthened by new ways of communication. Yet the attempt to exercise imperial control over the elaborate networks of communication never lost its precariousness.

${ }^{88}$ For general thoughts about the role of institutions in historical sciences see Gert Melville, 'Institutionen als geschichtswissenschaftliches Thema. Eine Einleitung', in: Institutionen und Geschichte. Theoretische Aspekte und mittelalterliche Befunde, Gert Melville, ed. (Cologne; Weimar; Vienna 1992) pp. 1-24, here p. 7.

${ }^{89}$ For this logic see also Wolfgang Balzer, 'Entstehung und Wandel sozialer Institutionen', in: Institutionen und Geschichte. Theoretische Aspekte und mittelalterliche Befunde, Gert Melville, ed. (Cologne; Weimar; Vienna 1992) pp. 73-96, here p. 86. 